\title{
Students' Future in the Virtual Sphere: Necessity of Personal, Social and Global Citizenship Education at Elementary Level
}

\author{
Hafiz Kosar \\ Ph. D Scholar \\ Department of Education, IUB \\ hafeezkausar.hashmi@gmail.com \\ Dr. Najam ul Kashif \\ Assistant Professor \\ Department of Education, IUB
}

\begin{abstract}
School education serves as ladder and the students of today are leaders of future. Future of the generations is in clutches of virtual sphere. Pakistan, being a developing country is also working to meet the challenges of the world and pace with it. From class 1 to 8, the subject of Social Studies is taught as a compulsory subject to teach personal, social and citizenship Education to Pakistani students. Presented study was designed to highlight the dire need of aforementioned education in bridging the virtual sphere as well as to identify how much Personal, Social and global citizenship is conceptualized through the curriculum of Social Studies and what more is required to add up. To achieve the aim of the study, documental analysis of the social studies curriculum and textbooks was done. Each level book was analyzed according to the set parameters given by OXFAM (2015) and UNESCO (2015) Guides for Schools. The findings revealed textbooks need to improve some areas.
\end{abstract}

Keywords: Global Citizenship, Personal and Social Education, Global Citizenship Education, School Education and Global Citizenship Education

\section{Introduction}

The individuals of the $21^{\text {st }}$ century generally have an inclination towards global identity. The forces of modern technologies are growing this global identity on a large scale. Among forces of modern era, new ways of communication, speedy information and transportation, and evolution of internet are most vital for this social change. The connectivity of the world is increasing through the use of internet technology. The Virtual-Sphere is a broader vision of this technology driven world. The term Virtual-Sphere not only encircles internet but its related technologies too. People will see their future world with many changes due to electronic media. Johannessen (2013) used 
the word virtual sphere when the internet is used in public sphere. Generally, the term virtual sphere is known as digitized future.

This study aims to address the potential global challenge in the field of education that educators around the world have to face. The concept of traditional citizenship has been changed with the rapid expansion of technology. The individuals around the globe are switching over to a broader concept of Citizenship - Global citizenship. In fact, actual problem arises when this concept knocked on the doors of education. Keeping in view the new demands, innovative objectives should be formulated to face the flood of technology. This study was planned to investigate the best solutions to resolve posing threats related to citizenship education.

New technology has strengthened our participation in the world-wide economy. People can easily travel and visit other parts of the world. All human beings feel empathy when they see pictures of disasters across globe and the affected people are helped easily from all the corners of the world. The forces of global engagement are developing feelings for oppressed ones and people raise their voice against any tyranny. The connectivity of world has shared feelings of pleasure and oppression too. The cruelty with one individual is taken as cruelty with all humans. At the same time, these forces are innovating people's identity as global citizens. As a matter of fact, global identity contradicts the construct of national citizenship. But many evidences highlight that people have to think and act less nationally and more globally to survive in the $21^{\text {st }}$ century. The world is on momentum of change; boundaries are getting weak, cultures are intersecting and the world has to face hybrid cultures. National identities are also changing due to Hybridism. This need raised questions of why and how do people become global citizens and during this socialization what consequences will occur on cultures.

Global citizenship has different perspectives. Individuals may get competency about global citizenship through diversity of ways. Socialization is increasing not only at local level but also at international level. Generally, it has is observed that socialization of youngsters created some serious problems which include careless behavior, drug abuse and adolescent pregnancy. In Pakistan's context, use of internet is so common like other countries. While comparing pros and cons of its frequent use the negative effects are more prominent. Easy access to pornography polluted the young minds. Due to ignorance and illiteracy, mostly people of Pakistan cannot avail the real benefits of this revolutionary media, though internet is present everywhere (Khan, 
2010). The situation is getting worse as traditional school has failed to prepare students according to hybrid society. Pakistan being an ideological state is supposed to have a long history of human rights and peace education but real situation is worse (Hassan, Azhar, Hassan, 2014). If present situation is taken as indication of future, then global citizenship is going to impart adverse effect on Nation's Islamic and Social values. Hence forward, the mere solution is present in the field of education.

In formal education, the schooling specially furnishes significant opportunities for consistent understanding of global citizenship. But practically, in formal school curriculum, global citizenship education is rarely found as learning area or a separate school subject. Where it is present as learning area, more often it is found integrated into a school subject such as Social Studies or a similar subject. It is hardly observed within the school curriculum education for personal, social and global citizenship. However, if any subject is not specified, it never means that personal and global citizenship education is ignored in school education or not taught. But in present, its identification is quite difficult. Though, Davies (2006) claimed about Global education that it exists since more than 40 years in one or other form.

Global Citizenship Education started with Oxfam publication "Curriculum Guide for Global Citizenship 1997" which was updated in 2015. Particularly in Pakistan, teaching of Global Citizenship Education is not evident in general public. So, it can be concluded that schools are not active to promote global citizenship education. In the same scenario, Print (2015) indicated that School curriculum is the key reason to hinder addressing global citizenship or global issues in school education. Since long, many efforts are made to accelerate global citizenship education such as in 1997, OXFAM presented curriculum for global citizenship education, UNESCO Global Citizenship Guide (2015). But only a few countries got little success to develop curriculum of Global Citizenship Education. Whereas going through the core themes of Global Citizenship Education, its future looks very bright. In Pakistan, present situation demands multifarious actions: development of a Global Citizenship Education curriculum, educating citizens for healthy body, active and pure character. As healthy mind develops in healthy body and both can be easily nourished through Personal and Social education. Let's have a bird eye view what is Personal and social education in real essence.

\subsection{Personal and Social Education (PSE)}


The school education is supposed to be responsible for effective personal and social education. PSE should train youngsters to understand challenges of socialization and they must be able to care about their physical and mental health. In this scenario, a report by Scottish Education and Skills Committee (2017) is worth mentioning. According to this report, 7 to 19 years old should be provided PSE. In views of Watkins (1999) coming century demands a connected view of school goals. Schlechty (1990) highlighted the upcoming needs of PSE curriculum such as Community Curriculum, Factory Curriculum, Hospital Curriculum and Work-Knowledge Curriculum. During schooling, students must learn how to "work smart". In this context, they need to develop systematic thinking, abstracting information, variety of collaboration, and experimental questioning (Reich, 1991). The schools should address all these skills effectively before youngsters enter in practical life.

Brotto (2018) stated that if students are active in their classrooms then they can be expected to play their role in their community. Nowadays, social networking sites are used for social connectivity, business use and knowledge sharing. But at the same time they have some adverse effects like anxiety, cybercrime and low self-esteem. As per Pantic (2014), if any connectivity proved in use of social media and psychiatric diseases, then it will be a serious threat because people cannot avoid its use. Before going to discuss Global Citizenship Education and its existence in Pakistan first have a glance what Global Citizenship means.

Global Citizenship (GC). 'Global citizenship' is recognized as responsibilities of every inhabitant on the planet. There is a variety of explanations how the term citizenship emerged as global citizenship. In view of Lagos (2001) individuals of multiple nations, for different reasons and activities move across boundaries both in north and south. Internet and telephone fostered communication and growing ease of travel facilitated this transnational activity. These activities resulted in emergence of global citizenry. But it is hard to give global citizens a legally defined political status or quantify them in numbers. Conceptually, citizenship itself has certain democratic and legal rights as The Oxford English Dictionary (OED, 2011) defines "citizen" as an inhabitant of a city or town, which possess civic rights and privileges. In an era of globalization, the meaning of citizenship in relation to multiple communities is considered an imagined understanding of individual (Print, 2015). In this reference, Osiadacz (2018) describes that Global citizenship phrase 
comprised of an adjective 'global' and a noun 'citizenship'; the combination of both indicates membership in a community. This community is made up of all the people in the world.

As in the early $20^{\text {th }}$ century, political and economic activities jumped from local affairs to global zone and same trend also emerged in educational discussions. Some major features of the term are enlisted on global citizenship website of OXFAM; a global citizen is an individual who has sense for his responsibilities, aware of wider world, accepts diversity and values it too. In the same scenario, Wintersteiner, Grobbauer, Diendorfer and Reitmair-Juárez, (2015) illustrated Global citizenship as an inevitable reality in networked world. This reality demands an individual's orientation in a world of varied lifestyles and values. In an increasingly changing world of work, it demands individuals' ability for making flexible political decisions and judging potential implications. In other words, political individuals who think globally are named global citizens. Pigozzi (2006) described global citizenship in view of UNESCO. According to his statement, UNESCO's central mission supports mutual understanding, universality, tolerance, mutual understanding, promotion of peace and respect for culture through acknowledging cultural diversity. No doubt, notion of global citizenship is echoed everywhere nowadays but practically it has some limits. When an individual faces issues of health care, he will neither go to World Health Organization nor to United Nations but will enact his national government that provides health care by law to him as citizen. Bates (2012) is also in view that global citizenship is not possible in strict legal terms though in metaphorical terms it can be defined in various ways but Parekh (2003) preferred the idea to be described as "globally oriented citizen" because the notion has no political home. Even then, international schools have a mission to enhance such citizenship. Davies, Evans and Reid (2005) stated the need to build a new form of global citizenship education allied with national frameworks instead of using outdated and unhelpful models of education.

Global citizenship is a skill based concept and in this context Ibrahim (2005) supports OXFAM's definition of global citizenship. Both stated that citizenship programs emphasize skills through participatory learning within the local community and school. If OXFAM (1997) curriculum for global citizenship is followed, the global citizenship can be expressed in an organized way. As per OXFAM definition, a global citizen knows the patterns of world including economic, political, social, cultural, technological and environmental works. In spite of all this significance, Global Citizenship Approach, for many schools, is like a checklist of requirements 
to be completed rather than a skill set to be developed and reflexive, critical mind-set to be trained (Aktas, Pitts, Richards \& Silova, 2016).Australian Curriculum Assessment and Reporting Authority- ACARA (2014) described global citizens are those people who have understanding of their rights and responsibilities at world-wide level. As stated in Oxley and Morris (2013) study, promotion of Global Citizenship (GC) is a new goal in school education of many countries. It indicates a tilt from national to global concept of citizenship. Some countries have incorporated GC in school subjects such as Civics and Social Studies. According to Davies (2006) argument, global citizenship is a linguistic fancy and simply a metaphor. As we are citizens of a country, in a similar way we cannot be citizens of the world. Hence to sum up the explanations of the concept, we may relate global citizenship to those people who possess some specific traits such as citizens having understanding to address global problems, ability to think in global perspective, have consideration for others beyond nationality and participate actively in global activities. Literature identified that traditional concept of citizen now developed as an international citizen. Following figure reveals what we expect from a global citizen and how attributes of Global Citizenship can be attained.

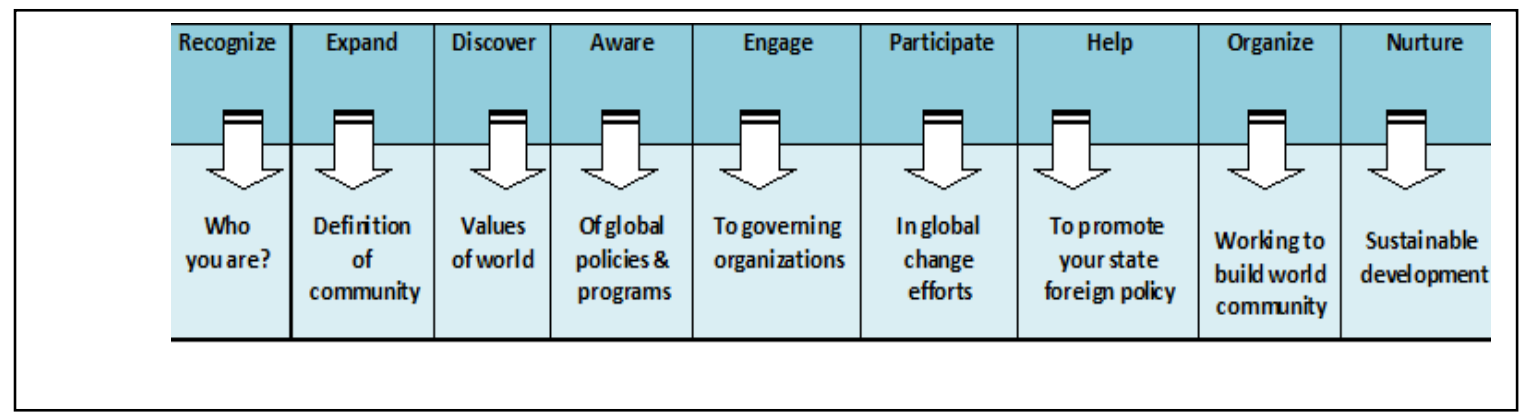

Figure 1: Steps for being a Global Citizen. Source: Own illustration

When seen GCE in context of Pakistan, we find handful research studies have attempted to explore students' understanding for the term. Furthermore, a clear understanding of 'citizenship' itself is not present here. In Pakistani schools, students do not learn skills of effective participation in democratic life and values for instance civic mindedness and critical consciousness (Dean, 2005; Naseer, 2012). Results of these studies highlighted the issue that Pakistan needs to rethink and redefine the concept of Global Citizenship from a local perspective.

Global Citizenship Education (GCE). The most debated significant vector for socialization is formal education. Educational institutions engage individuals' in positive activities. They 
participate in their community with sense of responsibility (Tawil, 2013). Recently, global education field has had to adapt international landscape. Now, it is a fast changing academic, technological and political phenomena (Marshall, 2009). The concept of Global Citizenship is an umbrella term that encircles citizenship education, global education, peace education and other pedagogies such as intercultural learning. Neither, it subsides other pedagogies nor it means those should be substituted by this new concept but GCE makes a connection among all of them (Wintersteiner et al., 2015). The fundamental objectives of UNESCO's education program for the next eight years are stated to develop empowered global citizens, build peace in nations and education for sustainable development. In promotion of universal values, raising awareness, encouraging reflection and promoting knowledge, GCE contribution is crucial (Keevy \& Matlala, 2016).But it is very important to decide for formal education institutes that at which level of education this transformative education is appropriate to implement. In the same scenario, OXFAM developed its curriculum in 1997 and published School Guide for Global Citizenship Education in 2006. According to OXFAM (2006), Global Citizenship education supports educational outcomes and gives priority to school-improvement at a broader level. Giving priority to Global Citizenship education, United Nations General Assembly developed an agenda of Sustainable Development Goals (SDGs). UN provision of quality education and access to universal education is necessary to prepare skillful youth of $21^{\text {st }}$ century. The First Initiative of Global Education by UN proceeds, "It is not enough for education to produce individuals who can read, write and count. Education must fully assume its central role in helping people to forge more just, peaceful, tolerant and inclusive societies." Educational institutes must prepare successful workforce for the $21^{\text {st }}$ century (Menten, 2015).

Although citizenship education, at all levels, gives rights and responsibilities exercised within communities but the responsibility lies on the shoulders of teachers and schools. The subject area of formal education for citizenship education as well as global citizenship education from formal curriculum at school level refers to social studies (Print, 2015). Davies (2006) discussed the complications and permutations between global, citizenship and education relationship. He posed some questions to define relationship of global citizenship and education such as what global citizenship education means? 


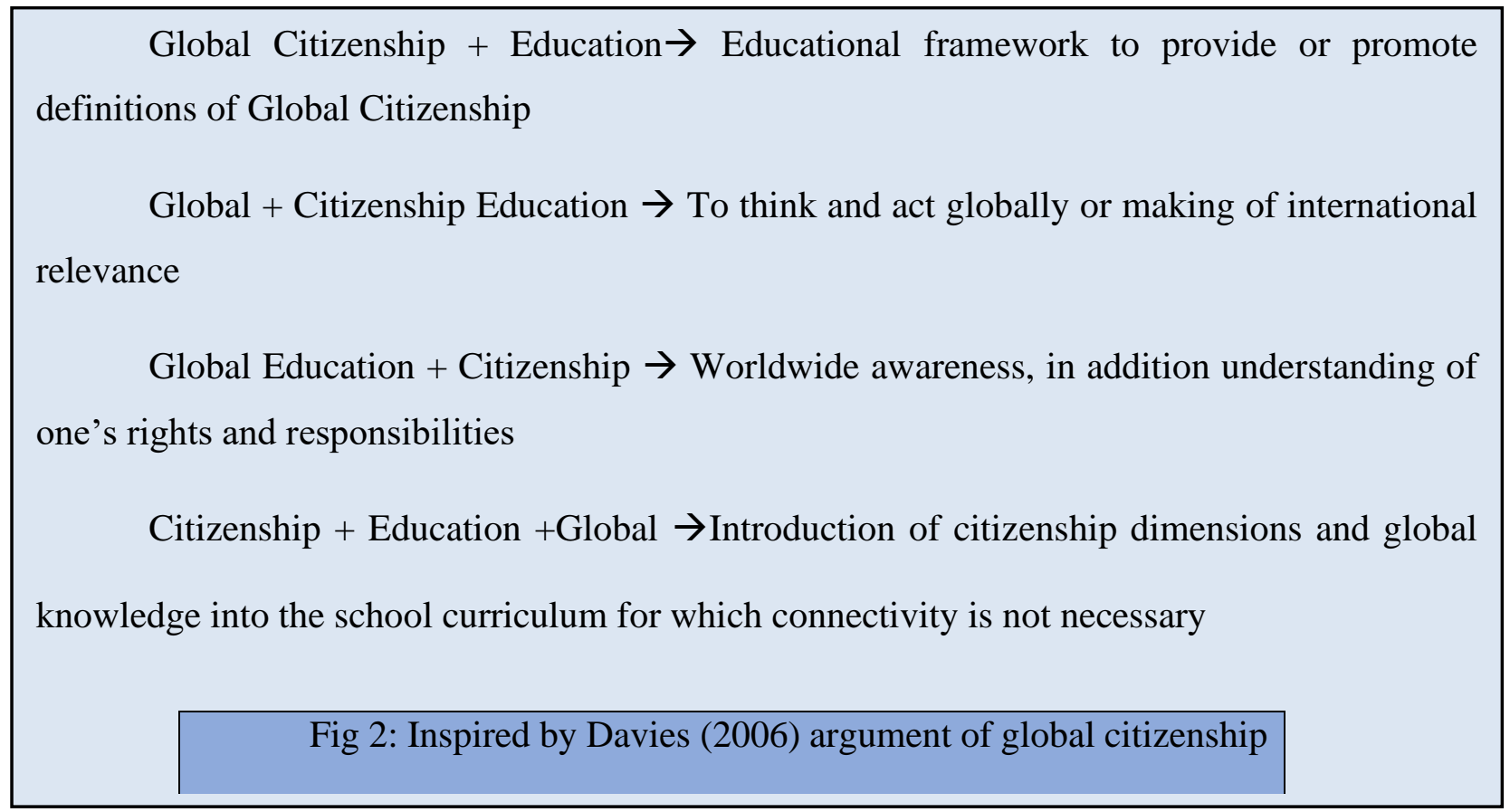

The Education for global citizenship has fundamental importance at school level. Children require a training to comprehend challenges which they may encounter through the media and their own experiences (OXFAM, 2006). The Global Citizenship Education (GCE) represents a conceptual shift and promotes transformation of culture. It also acknowledges methodologies and theories already implemented in different fields and subjects; applies a multifaceted approach. It aims to advance education for sustainable development, peace education, education for international understanding and human rights education. All these disciplines share a common objective of fostering sustainable world and GCE advances their overlapping agendas (UNESCO, 2014). The researchers' perspective for integration of Personal, Social and Global Citizenship Education through Social Studies is in same line.

In Pakistan, the school curricula were changed in 2006 and 2009. The new curricula were developed to face global challenges. Different international agencies and consultants were engaged to review curricula. In addition, present curricula also validate that the new curricula includes global themes. For practicing global education, Social Studies is considered more appropriate subject. Social Studies are taught at all levels of schooling in Pakistan. It changes its names at 
different levels (up to grade 5 as Social Studies, at elementary level as Geography and History, and at secondary and higher secondary level as Pakistan Studies). After making so many changes in the subject whether it is up to mark to develop global perspective in students or some more needs to be added. To answer the question, this paper included UNESCO and OXFAM's point of view regarding its implication.

\subsection{Research Objectives}

- To identify the extent of personal, social and global citizenship education, conceptualized in Social Studies textbooks of Elementary level,

- To find out what more can be added in textbooks to improve personal, social and global citizenship education in Pakistan.

\subsection{Research Methods}

This study was designed to investigate personal, social and global citizenship education related content in Social Studies textbooks used for elementary classes in Pakistan. Researchers followed a systematic procedure for content analysis. According to Krippendorf (2004) views, nature of content analysis is qualitative while Fraenkel and Wallen (2006) stated it as a technique of indirect communication. It follows some successive steps such as reading, interpretation; analysis in some context (Krippendorf, 2004). At first stage, topics and learning objectives of National Curriculum for Social Studies (2017) of Pakistan was compared with UNESCO (2015) guide for global citizenship education. A list of National curriculum document and UNESO (2015) Guide matched themes was noted. In second stage, one more list of topics from the same textbooks and curriculum document was developed comprised of the Personal and Social education themes. For second stage comparison, Wales Framework of Personal and Social Education (2008) were utilized. In third stage, under OXFAM (2015) guide for schools a list of existing educational themes was noted from textbooks. Finally, topics of personal and social education list were merged in the list of GCE themes and overlapped topics of both lists were sorted out. After making a combine list of PSE and GCE content analysis of textbooks was conducted. For the quality of content analysis seven (07) points were noted in each textbook of Social Studies, Geography and History following Grant and Sleeter (1991) presented steps as discussed in next lines. 


\subsection{Textbooks Analysis}

The list of outlined topics for PSE and GCE was comprised of personal security (Basic Human Rights), equity and social justice (via local to community then worldwide), self-identity and acceptance for diversity, interdependence and globalization, sustainable development, rights and responsibilities, governance and powers. Through extensive reading content of all these constructs were analyzed for quantity of concept, use of language, illustration, mentioned National heroes, institutions, storyline and end chapter exercises as outlined by Grant and Sleeter (1991).While analyzing quantity of concept clarity of given message was checked whether described in detail or just in few lines. During language analysis all value laden words conveying message for PSE and GCE were underlined. All topics of personalities related were identified and content was analyzed on why those personalities are included and what message is conveyed through their inclusion. To identify the nature of message involved illustration analysis. The intention of author and setting of message involved storyline analysis. How the concepts are reinforced and how students are engaged in practical activities was analyzed by end chapter exercises. All texts of similar construct in each book were marked and analyzed for extent and nature of message delivered either for PSE or for GCE.

\section{Research Findings}

The following table presents a comparison of Global Citizenship Guide of UNESO (2015) basic themes with Social Studies Textbooks of Pakistan.

Table 1: Basic Themes of UNESO for GCE vs. Basic Themes of Social Studies Textbooks

\begin{tabular}{|c|c|}
\hline Key Themes of UNESCO Guide & Key Themes of Pakistan's Textbooks \\
\hline $\begin{array}{l}\text { Pre-Primary and Lower Primary Level } \\
\text { Identity : (family.........world) } \\
\text { • Organisation of World: (regions to countries, } \\
\text { communities to groups, cities to villages ) }\end{array}$ & $\begin{array}{l}\text { Pre-Primary and Lower Primary Level } \\
\text {-Beliefs and prayers, Respect of other } \\
\text { religions } \\
\text {-Personal Identity and Identity of people } \\
\text { around }\end{array}$ \\
\hline
\end{tabular}


- Relations among families, communities, countries and then world

- Need of rules: Why to make and change after some time

- Rights and Responsibilities

\section{Upper Primary Level}

-Interconnectivity between local and global systems and structures

-Structure of interdependence in civil society, public and private sectors, political and economic alliances and international organizations

- Rights and Responsibilities: How Similarities and differences exist in different societies?

How rules and decisions work in different societies?

- Citizenship: Definition of citizenship and how similarities and differences are uphold in it

- Law of good governance, democracy and its process, transparency in governance

Lower secondary Level
-Manners and developing good character Examples from Life of Prophet Hazrat

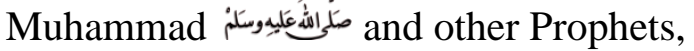

Forgiveness and being fair and just

-Rules and Responsibilities, Peace and Justice in World

- Significant features of country ,Natural , Human resources and their conservation

\section{Upper Primary Level}

-Citizenship: tolerance diversity, management of conflict and being citizen rights and responsibilities

$\checkmark$ Economics: Trade of goods and choice of services

-Government: How to make rule for ourselves?

-History: Present and past events and relevant personalities

Culture: nationality concept and diverse cultures of Pakistan

-Geography: Safety measures against disasters, Relationship of people and land 


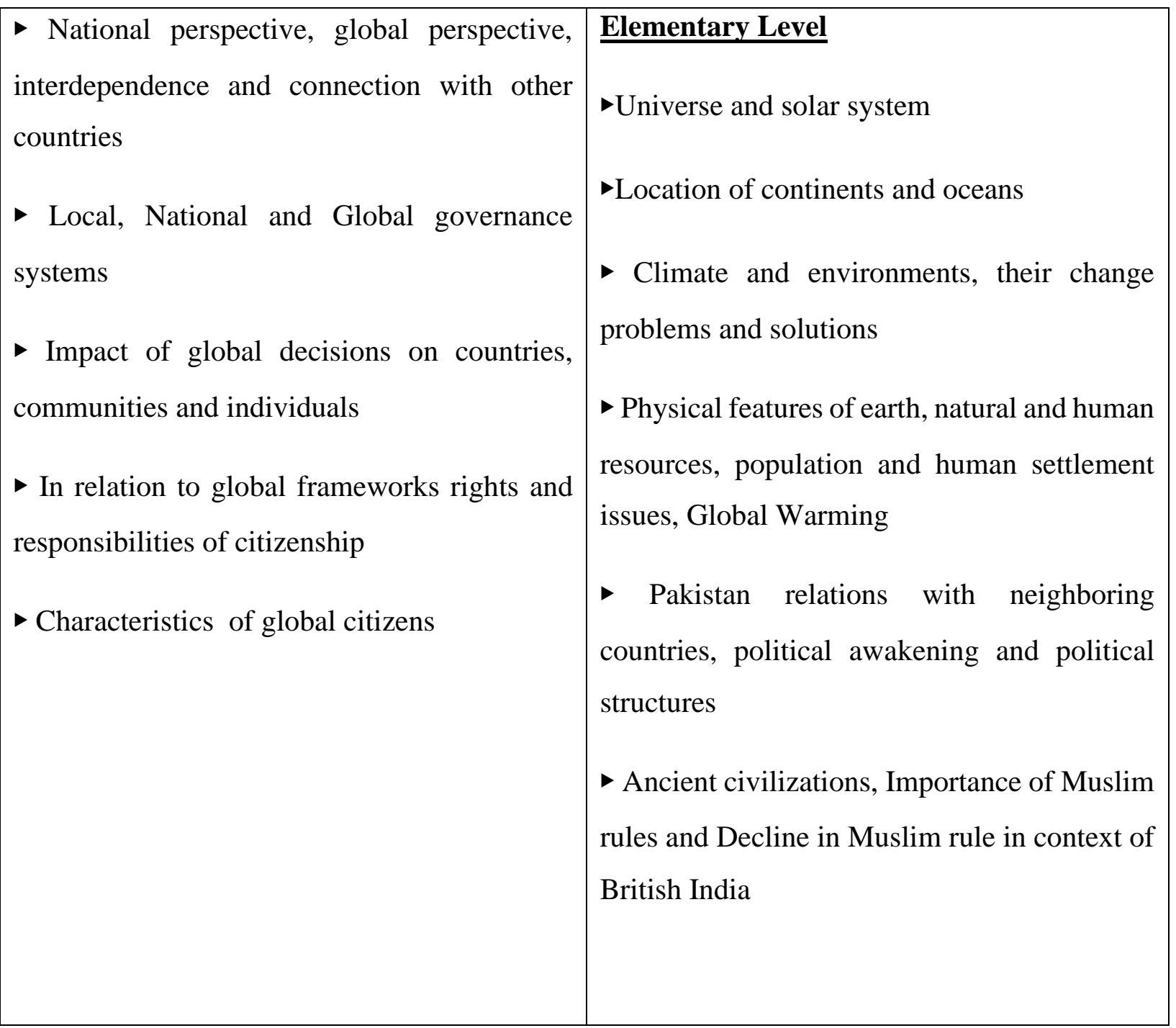

When the topics in Pakistani textbooks of Social Studies are matched with Global Citizenship Guide of UNESCO (2015) topics and objectives in lower primary and upper primary topics, sufficient similarity is found. But in the comparison of elementary level, apparently enough gaps are found such as global governance systems, impact of global decisions on the world, in relation to global frameworks rights and responsibilities of citizenship and the characteristics of global citizens are not added in textbooks. For more detailed analysis of social studies textbooks “OXFAM Curriculum Guide for Global Citizenship Education (2015) was used. According to key themes and sub themes of OXFAM guide a comparison of both showed some similarities and some differences. For content analysis, seven key themes of OXFAM Guide were identified in textbooks. First was the knowledge about security of all the basic rights of a citizen. Second were the concepts of equity in all the fields and social justice for everyone. Third was the understanding 
of diversity of cultures, societies and self- identity and fourth theme covered knowledge and deep understanding of interdependence of states on other nations of world and global connections. Fifth theme focused on the sustainable development of knowledge and sixth comprised of conflicts and peace theme. Seventh theme included the rules making activity, the importance of rules and different governance structures.

After detailed content analysis of key themes, it is revealed that language of the content is quite easy according to each age group respectively. But in Social Studies Textbooks from Grade I - VIII, some important concepts are not discussed such as the knowledge of basic human rights, causes and results of poverty at different levels, local and global initiatives to reduce poverty. Furthermore, the sense of belongings, dealing with conflicts at class level or local level and valuing rules at all levels are not found. The books discuss just federal system of government.

In new curriculum of social studies, Global Citizenship Education is integrated. The foundation of national unity is based on Islamic ideology but at the same time diversity is accepted. For instance, in Grade 2 topic "Religious Festivals" main festivals of other nations are also described along with Muslim festivals. The language of content reduces biasness against gender discrimination, religious groups and other nations."The Anmibya and Character Building" chapter 3 in class 2 textbook reduces religious biasness and shows that Islam accepts diversity and preaches for unity. These textbooks have multiple illustrations such as important lines of latitude and longitude, types of maps, different landforms, professions, historical places, developmental phases and types of climate etc. All these illustrations are attractive and comprehensible except maps. While analysis of the mentioned personalities, it was noted that included personalities are generally male and presented as superhuman. Their achievements and positive aspects of life are described such as Quaid- e -Azam handled creation of Pakistan. Though, they are included as role model but at same time, superhuman description de-motivates students for being social change agents. In the textbooks, different institutions like religious, social, judicial and political are mentioned at different levels (local to international).Charitable institutions are listed out. The texts describe principal functions of different institutions but their present performance is ignored. The texts of social responsibility highlight main responsibilities for example cleanliness, traffic rules and environmental pollution. As per storyline analysis, textbooks of social studies conveyed messages to students are as follows: 
Pakistan is Islamic, culturally homogeneous and a democratic state where selected representatives have power of governance. Islam commands justice, equality, tolerance and help for needy and all these messages are aligned with citizenship education. Factual questions and fill in items are given at the end-of-the-chapter exercises. Students learn facts from text and solve them but these exercises must be creative and after comprehending text students should apply it.

\section{Discussion}

As we all know that at long-winded road of Education, schooling is the first terminal. Young children take the first step towards destination and school education serves as ladder. In the long journey of life, experiences of school are unique. We mostly addle education with schooling but both have a thin line of difference; in simple words the formal way of educating children is schooling. Many explanations have been given in context of school role for gaining children's intellectual and cognitive skills. Similarly, Resnick (1987) discussed school as a 'place' where children are frequently engaged in activities; meanwhile they acquire knowledge. Schooling in fact develops intellectual abilities of students. The influence of formal education on the development of cognition and intelligence of individual is normally defined as the schooling effect. The effect of chronological age is reflected through the growth of brain structure, out-of-school learning, life experiences and psycho-physiological development but the effect of schooling is distinct from all effects (Cahan, Greenbaum, Artman, Deluya, \&Gappel-Gilon, 2008).

Literature review reveals that with the emergence of knowledge-based work, learning and awareness of workplace environment is more in need. With the quick changing world, the school curriculum must pace up significantly and attempt to equip students for this new momentum of era (Masters, 2015). Young people have high interest in learning about local and global issues (Weirenga et al., 2008). Unfortunately, present curricula of schooling are not enough according to present needs. In this context, Schiefelbein and McGinn (2017) commented over the clamor of dissatisfaction that despite impressive advances in the past decade defenders of today's schools have to speak loudly about effective schooling. Critics say that after completing school education, half of the students even can't understand texts and in the world's competitive economy their learning is irrelevant. Expectations from education are to produce a class-free society. It is hoped in virtual-sphere education's gift of knowledge will eliminate crime, violence and dissatisfaction. It will build a climate of trust and tolerance. According to OXFAM (2015) Guide, 
Global Citizenship Education aligns three areas, citizen's education, education of international understandings and education for sustainable development. But with lack of global citizenship exposure, a school curriculum can't develop a sense of global citizenship among students (UNESCO, 2014). Certainly, implementation of GCE at school level is not so easy task even educators of developed industrialized countries as Buchanan, Burridge and Chodkiewicz ( 2018) stated, educators of Australia faced significant challenges in maintaining education about global issues and citizenship in schools.

In prevailing situation, a significant rethink of the school curriculum is the need of the moment. In present situation it seems, the objectives of school curriculum must have greater priority for skills and attributes. According to OXFAM (2015), present requirements for workforce include collaborative work, problem solving, and engaging real-world problems. So, we need develop students' deep understandings for essential disciplinary concepts and principles. They must have ability to apply these understandings to complex skills for communicating; creating and using technologies (Masters, 2015). Same is supported by Massey's (2014) study which sampled students of Grade 12. Participants of study were asked about acting as a global citizen and buy fair trade products. Furthermore, being a volunteer they were asked to donate for charity but their responses were limited to such actions. Though, in their Geography class had included global education component. They were supposed to develop a stronger global awareness and sense of belonging to the wider world. The findings point out holistic experiential approaches being taken in school programs for effective learning.

Cleajoy (2018) also supports Global Citizenship education at school level. As per his view, we interact with people of different talents who have unique skills belong to different places with their personal advocacies. So, the addition of GCE into the curriculum produces an opportunity to develop the curriculum content. It will inculcate global competency among students teaching and assessment practices. The students will be equipped for broad interconnected world through incorporating the global competence to the education system.

As global citizenship education (GCE) is more than literacy; it comprises topics of citizenry and intend to develop more tolerant, peaceful and just societies. It is crucial question for educators and policy makers to develop new programmes which may acquire objectives of producing global citizens. But what might attract the citizen for bypassing the local and going straight to the global 
is the question for educationists. Teachers, educators and people connected with education are becoming more and more interested in any information related to education. Same situation is in other departments of life. Now schools of today have more diversity as compared to past (Futrell, Gomez, \&Bedden, 2003). Now the foreign born population is also observed for this global citizenship. Mexico, China, the Philippines, India, Viet Nam, El Salvador, Korea, Cuba, Canada, and the Dominican Republic are considered the 10 leading countries that have by birth foreignborn population of United States (Kandel, 2011). Foreign-born population in Asians is approximately 27\% (Grieco\& Trevelyan, 2010). In this phenomenon of diversity, Global Citizenship Education Curriculum seems inevitable. But literature identified Global Citizenship Education in schools is facing multiple key challenges. Global Citizenship Education itself is a challenge for policy makers and curriculum decision makers as it lagged behind due to many issues. The following table presents global curriculum challenges with potential solutions.

\section{Table 2: Challeges to GCED and potential solutions}

\begin{tabular}{|c|c|c|}
\hline \multicolumn{2}{|c|}{ Challenges } & Solutions \\
\hline GCED is poorly regarded by & More money for programmes, more \\
\hline educational policy makers and curriculum & time for planning and shift in attitudes \\
\hline decision-makers & Management's new approach on \\
\hline as a separate school subject & curricula designing may change the situation \\
\hline
\end{tabular}




\begin{tabular}{|c|c|}
\hline $\begin{array}{l}\text { Incorporated within a broader field } \\
\text { subject and treated at the interest or whim of } \\
\text { the teacher }\end{array}$ & $\begin{array}{l}\text { Generally teachers are content driven } \\
\text { so they need having a global perspective in } \\
\text { their classroom despite their content }\end{array}$ \\
\hline $\begin{array}{l}\text { Lacks in research for giving } \\
\text { justification in the school curriculum }\end{array}$ & $\begin{array}{l}\text { Empirical studies can prove that global } \\
\text { based learning enhances academic excellence }\end{array}$ \\
\hline $\begin{array}{l}\text { School are less supportive to motivate } \\
\text { teachers in teaching the subject matter of } \\
\text { global citizenship }\end{array}$ & $\begin{array}{l}\text { To introduce the concept and to make } \\
\text { it easier, international NGOs should foresee } \\
\text { programmes in their country }\end{array}$ \\
\hline $\begin{array}{l}\text { Challenges include monitoring of } \\
\text { school students for global behavior }\end{array}$ & $\begin{array}{l}\text { Students' motivation and interest, their } \\
\text { collaboration with other students is a result }\end{array}$ \\
\hline $\begin{array}{l}\text { Initial teacher education programmes } \\
\text { are not sufficient }\end{array}$ & $\begin{array}{l}\text { Arranging conferences and workshops } \\
\text { or in-service courses for teachers can raise } \\
\text { global education awareness }\end{array}$ \\
\hline
\end{tabular}

Future of our planet is at risk. What the best educated and interconnected generation of today is planning to leave for grandchildren' inheritance? To deal with the $21^{\text {st }}$ century global issues our country should not only participate in developing Global Citizenship Education Curriculum to make their generations equipped in competitive market with similar skills but for the care of Islamic values we need a fence of personal education. Social Studies help young people to deal with culturally diverse, democratic societies in the world. Its curriculum enables students about the ideas and values of democracy. They are prepared as active and informed citizens. Its curriculum is designed for reflective, interpretive knowledge and skills. Through variety of learning activities students have progressive learning experience of knowledge, skills and attitude. Social Studies curriculum is enabling students' identification for innovative solutions of current 
and persistent issues. Therefore, with the integration of Global Citizenship Education themes and skills in present curriculum learning will be more effective and practical for virtual sphere students.

\subsection{Conclusion.}

Personal, Social and Global citizenship education can be easily adjusted within content boundaries of school subjects. Each subject of school curricula can play important contribution in promotion of Global Citizenship Education. Although all subjects of school curricula can make a good contribution in promoting global citizenship subject but social Studies and its relevant subjects are most appropriate for promoting this new combination of Personal, Social and Global citizenship education. If Government develops a specific curriculum and suitable educational activities in accordance to our national aims, our students will easily adjust in virtual-sphere.

\subsection{Suggestions.}

The Curricula on global citizenship education by OXFAM and recent work in this area by UNESCO for publishing topics and learning objectives of Global Citizenship Education made the way easy to devise curricula of Global Citizenship Education for all countries according to their needs. Including the core competencies, goals and learning objectives as well as the priorities for assessing and evaluating learning can easily be adapted to different national and local contexts. These can and should be complemented by topics and issues that are locally relevant and appropriate and can also be assimilated in existing work of related areas. In this case, new issues that continually emerge can be added to already existing topics.

Suggestions for Curriculum Developers. According to National Curriculum Document of Pakistan (2017), Social Studies curriculum is designed to make skilled and knowledgeable citizens. This new curriculum, to some extent, considered outlines of UNESCO Guide. But during extensive content analysis, it is noticed that some core themes are just presented in a few lines and some activities should be added to make clear understanding of those concepts. Although the present textbooks have some topics of self-identity and relationships but in care of potential risks to our value system some suggestions are given for Personal and Social Education (PSE) addition in textbooks.

PSE at Pre/Lower Primary Level. The content should be activity based; about concepts of family bonding, self-esteem, moral values and beliefs. For enjoyment activities, positive environment should be planned. Concept of good and bad pastimes should be introduced at this stage. 
PSE at Upper Primary Level. PSE should offer personal responsibility of being safe. Development of effective relationships with peers and beyond school should be exercised. They must be equipped to face the changes at puberty. To communicate with wider world activities should be added in books.

PSE at Elementary Level. The students should be equipped with greater self-assurance. Practice should be given to use media positively. Exercises to deflate peer pressure and active citizenship should be planned for this level.

\section{Table 3: Domains for Suggested Global Citizenship Education}

Cognitive Domain: Provide interrelated knowledge of local, national, regional, and global issues

Socio-emotional Domain: Create a sense of identity, diversity, humanity, empathy, sharing values and respect for differences.

Behavioural Domain: Opportunities to act effectively for a more peaceful and sustainable world at all levels

Source: Adapted by Topics and learning objectives of GCED by UNESCO (2015)

\section{References}

Aktas, F., Pitts, K., Richards, J. C., \& Silova, I. (2016). Institutionalizing global citizenship. Journal of Studies in International Education, 21(1), 6580.doi:10.1177/1028315316669815

Australian Curriculum, Assessment and Reporting Authority [ACARA] (2014). The Australian curriculum humanities and social sciences - Civics and citizenship. ACARA: Sydney

Bates, R. (2012). Is global citizenship possible, and can international schools provide it? Journal of Research in International Education, 11(3), 262-274. doi:10.1177/1475240912461884

Brotto ,G.(2018). Social-emotional learning: Why it matters and how to foster it? Retrieved from: https://www.edsurge.com/research/guides

Buchanan, J., Burridge, N., \& Chodkiewicz, A. (2018). Maintaining global citizenship education in schools: A challenge for Australian educators and schools. Australian Journal of Teacher Education, 43(4). Retrieved from http://ro.ecu.edu.au/ajte/vol43/iss4/4 
Cahan, S., Greenbaum, C., Artman, L., Deluya, N., \& Gappel-Gilon, Y. (2008). The differential effects of age and first grade schooling on the development of infra logical and logicomathematical concrete operations. Cognitive Development, 23, 258-277.

Cleajoy (2018). Five reasons why global citizenship education should be part of your curriculum? Retrieved from: https://www.afs.ph

Davies, I., Evans, M., \& Reid, A. (2005). Globalising citizenship education? A critique of "global education" and "citizenship education." British Journal of Educational Studies, 53(1), 6689. doi:10.1111/j.1467-8527.2005.00284.x

Davies, L.(2006).Global citizenship; abstraction or framework for action? Educational Review 58(1), 5-25. doi:10.1080/00131910500352523

Dean, B. L. (2005). Citizenship education in Pakistani schools: Problems and possibilities. International Journal of Citizenship and Teacher Education, 1(2), 35-55.

Fraenkel, J. R. \& Wallen, N. E. (2006) How to Design and Evaluate Research in Education (6th ed.), New York: McGraw-Hill

Futrell, M. H., Gomez, J., \& Bedden, D. (2003). Teaching the children of a new America: The challenge of diversity. Phi Delta Kappan, 84, 381-385.

Grant, C.A. \& Sleeter, C.E. (1991). Race, Class, Gender, and Disability in Current Textbooks. InFlinders, D.J. and Thornton, S.J. The Curriculum Studies Reader. London: Routledge, 279-301

Grieco, E. M., \& Trevelyan, E. N. (2010). Place of birth of the foreign-born population: 2009. Washington, DC: U.S. Census Bureau, American Community Survey, 2009. Available from: www.census.gov/prod/2010pubs/acsbr09-15.pdf

Hassan,S. M., Azhar,T. \& Hassan,T.( 2014). Educating peace in Pakistan. Journal of Education and Practice, 5(17)

Ibrahim, T. (2005). Global citizenship education: Mainstreaming the curriculum? Cambridge Journal of Education, 35(2), 177-194.

Johannessen, M. R.(2013).Social media as public sphere.Doctoral Dissertation University of Agder, Kristiansand.

Kandel, W. K. (2011). The U.S. foreign-born population trends and selected characteristics. Washington, DC: Congressional Research Service Report R41592. Retrieved from: www.fas. org/sgp/crs/misc/R41592.pdf

Keevy, J. \& Matlala,R.(2016). Global citizenship education in Southern Africa. https://www.academia.edu

Khan, G.A.(2010). Globalization and Pakistan, some realities. Adwa Vol. XXIV, SZIC, PU,

Lhr

Krippendorf, K. (2004). Content analysis: An introduction to its methodology. Thousand Oaks, CA: Sage Publications, Inc.

Lagos, T. G. (2001). Global citizenship - towards a definition. Retrieved from: http://depts.washington.edu/gcp/pdf/globalcitizenship.pdf 
International Journal of Distance Education and E- Learning (IJDEEL) Volume V- Issue II (June, 2020)

Marshall, H. 2009. Educating the European citizen in the global age: Engaging with the postnational and identifying the research agenda. Journal of Curriculum Studies, 41(1): 247-267.

Massey, K. (2014). Global citizenship education in a secondary geography course: The students' perspectives. Review of International Geographical Education, 4(2), 80101. ISSN: 21460353.

Masters,G.(2015.) 'Big five' challenges in school education. Retrieved from: www.teachermagazine.com.au

Menten, A. (2015).What is 'Global Citizenship Education'? Retrieved From: https://asiasociety.org

National Curriculum Document of Pakistan (2017).Curriculum for Social Studies. Ministry Of Federal Education \& Professional Training, Islamabad, Government of Pakistan.

Naseer, R. (2012) 'Citizenship education in Pakistan.' Pakistaniaat:A journal of Pakistan Studies, $4(3), 1-16$.

OED (2011). Citizen-In Oxford English dictionary (3rd ed.). Retrieved from http://dictionary.oed.com

Osiadacz,E.(2018). Global citizenship. Brock Education Journal, 27(2)

Oxfam, 1997, A Curriculum for Global Citizenship. Oxford: Oxfam.

OXFAM ,2006, Education for global citizenship: A Guide for Schools: http://www.oxfam.org.uk

Oxfam G.B.2015, Education for Global Citizenship: A Guide for Schools. oxfam.org.uk/education.

Oxley,L. \& Morris,P. (2013) Global citizenship: A typology for distinguishing its multiple conceptions, British Journal of Educational Studies, 61:3, 301-325, DOI: 10.1080/00071005.2013.798393

Pantic, I. (2014). Online Social Networking and Mental Health. Cyberpsychology, Behavior, and Social Networking, 17(10), 652-657.doi:10.1089/cyber.2014.0070

Parekh, B. (2003) Cosmopolitanism and Global Citizenship. Review of International Studies. 29, 3-17.

Pigozzi, M.J (2006). A UNESCO view of global citizenship education. Education Review, 58(1), 1-4. doi:10.1080/00131910500352473

Print, M. (2015). A global citizenship perspective through a school curriculum. Contesting and Constructing International Perspectives in Global Education, 187-198. doi:10.1007/97894-6209-989-0_16

Reich, R.B. (1991). The Work of Nations: Preparing Ourselves for $21^{\text {st }}$ Century Capitalism. New York: Knopf.

Resnick, L. (1987)Education and learning to think. Washington, DC: National Academy Press.

Schiefelbein E. \& McGinn N.F.(2017). Introduction: Schooling and education. In: Learning to Educate. Ibe on Curriculum, Learning, And Assessment. SensePublishers, Rotterdam 
Schlechty, P.C.1990, Schools for the Twenty-First Cenruy: Leadership Imperatives for School Reform. San Francisco: Jossey-Bass

Scottish Education and skills Committee (2017). Let's talk about personal and social education. Retrieved From:http://www.parliament.scot/abouttheparliament/91279.aspx

Tawil,S. (2013) Education for 'global citizenship': A framework for discussion. Retrieved From: www.researchgate.net/publication/318760972

UNESCO (2014): Global Citizenship Education. Preparing learners for the challenges of the twenty-first century, available at http://unesdoc.unesco.org/images/0022/002277/227729e. pdf Paris: UNESCO

UNESCO (2015). Global Citizenship Education: Topics and learning objectives.7, place de Fontenoy, 75352 Paris 07 SP, France

Watkins, C. (1999). Personal-social education: Beyond the national curriculum. British Journal of Guidance \& Counselling, 27(1), 71-84.doi:10.1080/03069889908259716

Wierenga, A. Wyn, J. Guevara, J. R. Gough, A. Schultz, L. Beadle, S. Ratnam, S. \& King, J. (2008). Youth-led learning: Local connections \& global citizenship. Research Report 31. Melbourne: Australian Youth Research Centre, University of Melbourne.

Wintersteiner,W., Grobbauer,H., Diendorfer,G. ， Reitmair-Juárez,S.(2015). Global citizenship:Education citizenship education for globalizing societies. In cooperation with the Austrian Commission for UNESCO : Klagenfurt, Salzburg, Vienna 